\title{
Definindo o republicanismo: abordagens, dificuldades e síntese
}

Luís Falcão'

\section{Resumo}

O artigo apresenta uma síntese das diferentes e recentes definições do republicanismo. Para isso, empreende-se uma avaliação crítica dos diversos modos como essas definições são empregadas e, assim, debatem-se os anteparos do republicanismo em relação a tradições que se lhe opõe, a embocaduras tautológicas e a extrapolações indevidas. Num segundo momento, argumenta-se que a suposta exceção francesa deve ser lida de modo crítico e que seus pontos de contato com o universo anglo-saxão não são incomuns. Na sequência, evidencia-se a estratégia de definição por um ângulo histórico e são debatidas as implicações. Por fim, o artigo argumenta que as definições excessivamente normativas e que dialogam explicitamente com a teoria política contemporânea incorrem em contradições históricas. Propõe-se, então, uma síntese que congrega conceito e contexto.

Palavras-chave: Republicanismo. Exceção francesa. Reconstrução histórica. Definição Normativa.

\section{Introdução}

Desde a retomada dos estudos sobre o republicanismo em meados do século XX, o campo tem sido hegemonizado por pesquisas de orientação anglo-saxã, tanto no que concerne a pesquisadores mais destacados quanto à sensibilidade dos temas. Zera Fink, Caroline Robbins, Bernard Baylin, Gordon Wood, J. G. A. Pocock e Quentin Skinner estão entre os autores

I Professor do Departamento de Ciência Política e do Programa de Pós-Graduação em Ciência Política da Universidade Federal Fluminense, onde coordena o Laboratório de Estudos Republicanos (LER). Autor de Maquiavel, Montesquieu e Madison: uma tradição republicana em duas perspectivas (Rio de Janeiro: Azougue, 2013); Algernon Sidney: um pensador republicano do século XVII (Niterói: EdUFF, 2019); Algernon Sidney between modern natural rights and Machiavellian republicanism (Newcastle, England, Cambridge Scholars Publishing, 2020) e Ensaios Republicanos (Curitiba: Appris, 2021).

\section{$(\mathrm{cc}) \mathrm{Br}$}

Direito autoral e licença de uso: Este artigo está licenciado sob uma Licença Creative Commons. Com essa licença você pode compartilhar, adaptar, para qualquer fim, desde que atribua a autoria da obra, forneça um link para a licença, e indicar se foram feitas alterações. 
centrais dessa reconstrução da história e dos fundamentos do pensamento político moderno. Em regra, atêm-se ao renascimento italiano, às guerras civis inglesas e seus desdobramentos e à revolução americana cujo argumento central, não obstante as particularidades, destina-se a destacar o papel do pensamento republicano no Ocidente moderno.

A notável centralidade do percurso "ítalo-atlântico", para empregar a expressão que comumente resume os termos de Pocock, omite ou nega a importância continental e, sobretudo, francesa. De fato, autores como Montesquieu, Mably e Rousseau, sem mencionar personagens de destaque da revolução e do século XIX, não ganham atenção nessas pesquisas. $\mathrm{O}$ trabalho de Pocock, porém, não deve ser tomado como um resumo do republican revival, porque ele se inscreve na lógica da ação política, da participação cidadá, no contraste entre a virtù e a fortuna e o tema da corrupção dos regimes políticos, distanciando-se, portanto, de interpretaçóes mais aproximativas com o liberalismo ${ }^{2}$. Ainda que esses temas tenham sido tratados nas demais publicaçóes, elas colocam em destaque, sobretudo com Skinner e as pesquisas que se desenvolveram a partir das suas, o tema da liberdade. Assim, já em fins do século XX, o republicanismo concatenou as reconstituiçôes históricas com uma embocadura efetivamente normativa a partir do conceito de liberdade em torno do debate com o liberalismo contemporâneo ${ }^{3}$.

Essa inflexão do campo teve Philip Pettit como autor central, cuja base teórica reside no conceito de liberdade como náo dominação, que, segundo ele, se diferiria tanto da versão da liberdade positiva quanto da liberdade negativa, caudatárias de Isaiah Berlin ([1958] 1997). Chama a atenção o fato de que, nas últimas décadas, os trabalhos de caráter mais normativo não abandonaram a perspectiva histórica, vinculando o ideal de liberdade como não dominação à tradição "ítalo-atlântica” (DAGGER, 1997; HONOHAN, 2002). O republicanismo seria, nesse sentido, uma tradição teórica e um ideal normativo fundamentalmente anglófono, eivado pelo renascimento italiano, sobretudo a partir de Maquiavel.

2 O próprio Pocock (2003, p. 553-556) tem uma visão crítica dessa aproximação.

3 Não trataremos especificamente do conceito de liberdade aqui, cf. Silva, 2015; Falcão, 2017. 
Assim, o campo ganhou espaço nos debates contemporâneos mais proeminentes no universo anglo-saxão, como os diferentes liberalismos e o comunitarismo, reivindicando que o conceito republicano ou neorromano de liberdade seria mais adequado e mais amplo para as sociedades contemporâneas porquanto resguarde o indivíduo e mantenha um vínculo participativo apenas instrumental, com uma concepção neutra de Estado do ponto de vista moral. Além disso, as recentes contribuições do republicanismo visam a se diferenciar de liberais e comunitaristas pelo fato de, segundo Pettit (1997, p. 206) e Skinner (1984, p. 234, 2002a, p. 242, 2002b, p. 189), o republicanismo não atribuir qualquer valor intrínseco à natureza humana, o que, via de regra, poderia ser estendido a toda a modernidade republicana. A reunião dessas vantagens, argumentam, superaria os pontos fortes de um liberalismo igualitário e da ética comunitarista (BELLAMY, 2008). Os pilares desse republicanismo, histórico e normativo, quase sempre ignoram as contribuiçóes francesas e, mesmo quando interpretados, negam que, por exemplo, Rousseau seja um pensador republicano (PETTIT, 1997, p. 252-253, 2012, p. 12), seja porque a tradição francesa é distante dos termos do momento maquiaveliano, seja porque ela concebe a liberdade de um modo desvinculado da não dominação.

As reações a essa negação têm surgido em anos ainda mais recentes e tornado o campo republicano mais rico, complexo e multifacetado. Inúmeras pesquisas têm chamado a atenção para o silêncio do republicanismo diante da contribuiçáo francesa ao campo e evidenciam o caráter excepcional das teorias desenvolvidas nesse país ou interpretam-no com o conceito de liberdade próximo da argumentação anglo-saxã (SPITZ, 1995). De fato, as marcas do republicanismo francês se diferem daquelas do anglo-saxão, pois se inscrevem nos termos da revolução de 1789.

Diferentemente das guerras civis inglesas, a república na França não surge como consequência da derrocada da monarquia, mas essa é sua causa, e, afastando-se da revolução americana, os ideais de representação local e federalismo náo encontraram eco nas correntes mais poderosas daquele contexto. Poder-se-iam acrescentar à exceção francesa a questão social, a unidade nacional, a educação universal e laica e o antimonarquismo como princípios estruturantes. Esses termos são, de fato, estranhos à linguagem 
republicana ítalo-atlântica, de tal maneira que se torna compreensível a crítica francesa.

Além disso, outros trabalhos (SILVESTRINI, 2008; KRIEGEL, 1998; ZUCKERT, 1994) mostram um intenso diálogo entre o que se constituiu na França a partir do século XVIII como republicanismo e filosofias do direito e sistemas contratualistas continentais de uma gama de autores que vai de Hugo Grotius a Jean-Jacques Burlamaqui, passando por Espinosa, Samuel Pufendorf, Locke e outros dos quais Rousseau era um grande interlocutor. $\mathrm{Na}$ verdade, a reconstituição do republicanismo francês tem corroborado com a hipótese de Maihofer (1990) ou produziu a inspiração em Pettit (2013) de que, na verdade, o Ocidente possuiria duas tradiçóes republicanas, a ítalo-atlântica, na qual o próprio Pettit se inscreve, e a continental. Mas, continua Pettit (2013), ambas devem ser contrastadas pelo conceito de liberdade, o que, definitivamente, não é aquilo que mais mobiliza as reconstituiçóes e definiçôes recentes.

Não estamos diante de uma querela historiográfica, cujo objetivo central seria identificar em diferentes contextos e tradiçôes nacionais o caráter específico de cada republicanismo, mas do entendimento conceitual do que seja o republicanismo e, em versóes mais entusiasmadas, de um projeto normativo orientado para as democracias da atualidade (HAMEL, 2007, 2019). Nesse ponto, o problema começa a ganhar corpo. Se, por um lado, há certo consenso entre os principais autores anglo-saxóes de que o conceito de liberdade é central na tradição e nas possíveis agendas republicanas, por outro, as contribuiçóes francesas apontam, cada uma, para um rumo.

Todo esse quadro leva a crer em duas escolas contemporâneas de reconstituiçáo e definiçáa do republicanismo, que não apenas ensejam, supostamente, duas tradiçóes distintas, mas, sobretudo, enfatizam conceitos distintos para a condução do problema. Ao invés de buscarmos uma problematização das obras pioneiras que abriram o campo de pesquisa em meados do século passado, o presente artigo se propóe a verificar na literatura mais recente especializada e nas obras de divulgação dos estudiosos do assunto as diferentes definiçóes e embocaduras para se definir e compreender o republicanismo. Desse modo, necessitamos restringir nosso objeto às 
obras que atacam diretamente o problema da definição do republicanismo e deixar de lado aquelas pioneiras, que forneceram as bases dessa empreitada. É certo que a preocupação inicial de, por exemplo, Fink, Robbins, Baylin, Wood, Pocock, um primeiro Skinner e os trabalhos dos anos 1990 de Pettit não remetia prioritariamente a uma definição de republicanismo, mas alguma definiçáo de republicanismo foi-lhes retirada pela sequência dos estudos no campo ${ }^{4}$. Trata-se nesse artigo, afinal, de uma revisão crítica do campo cuja hipótese central reside não na oposição entre inconciliáveis republicanismos, mas no fato de que seja possível construir uma síntese. Deve-se atentar, portanto, para a ênfase que cada intérprete deu sobre uma definição de republicanismo; afinal, na verdade, ela diz mais a respeito de sua própria posição teórica dentro do campo do que visa atentar para uma possível síntese (KALYVAS; KATZNELSON, 2018, p. 170; TENZER, 1993 , p. 74, 87, 119). Isso quer dizer que os conceitos repetem-se e confirmam-se entre aqueles autores que se opóem mutuamente, embora a ênfase seja inteiramente distinta.

Nesse sentido, concluiremos que é possível tecer uma síntese sobre o republicanismo a partir do cruzamento de conceitos e contextos de um modo muito preciso. A centralidade de alguns conceitos-chave pode ser identificada pela recorrência em que eles aparecem e estruturam cada definição atual. Do mesmo modo, a importância de cada conceito em relação a outro varia de acordo com o contexto de cada aparecimento moderno do republicanismo. Isso mostra o importante alinhamento entre as interpretações recentes - por exemplo, a anglo-saxã e a francesa - e a ênfase dada a cada contexto e a cada país - de um lado, guerras civis inglesas e revolução americana; de outro, a revolução francesa com seus desdobramentos, respectivamente. Em suma, sustentamos que o contexto oferece a ferramenta necessária para compreender a importância relativa de cada conceito republicano, mas este não determina por si mesmo quais sejam esses conceitos.

4 As edições revisadas de algumas dessas obras trazem, no mais das vezes, complementos às versões originais que lateralmente expõem a posição de cada autor sobre a atualidade do debate e das definições de republicanismo. Conforme, ao menos: Pocock, 2003; Pettit, 1999; Skinner, 1998. 


\section{As diferentes abordagens}

A dificuldade de um estudo inicial do republicanismo reside na diversidade de abordagens que têm sido apresentadas nas últimas décadas e que acabam por conformar diferentes definiçóes ${ }^{5}$. As obras que se pretendem introdutórias ao tema, geralmente, carregam a concepção própria do autor para o republicanismo e seus conceitos mais efetivos, as demais possuem um caráter mais ou menos historicamente construído ${ }^{6}$.

Além disso, o republicanismo é uma tradição de pensamento que, academicamente, ainda está em processo de se estabelecer, se for comparado a outras. Isso náo quer dizer que a presença do republicanismo no pensamento político ocidental seja menor, mas que os esforços de síntese e investigação profissional são demasiadamente recentes para que haja consensos bem estabelecidos. Tomando o campo republicano como um todo, é possível agrupar os estudos em quatro grandes grupos: 1) os trabalhos mais enciclopédicos; 2) as obras generalistas ou introdutórias voltadas para resumo; 3 ) as obras de caráter histórico de toda a tradição, de um país, de um contexto ou de um autor; e 4) as obras mais marcadamente normativas (KALYVAS; KATZNELSON, 2018, p. 3). De algum modo, todas as obras apresentam um conceito ou uma interpretação de republicanismo, o que significa, aliás, um esforço constante de adequação entre história e conceitos.

5 O rigor metodológico e o debate ao qual se seguiu a partir das contribuições profundamente impactantes para toda a área de teoria política da chamada Escola de Cambridge mereceria um estudo à parte. Não pretendemos aqui realizar ou propor qualquer significado metodológico stricto sensu, mas buscamos interpretar a estratégia discursiva dos diferentes modos pelos quais o republicanismo é apresentado e sintetizado.

6 Na escolha das obras, optamos pelo critério de que deva ter explicitamente o objetivo de definição e conceitualização do republicanismo, seja introdutório ou voltado para um público especializado, não importando se a estratégia de apresentação seja uma reconstituição histórica ou uma apresentação analítica, e que, de algum modo, dialogue com o próprio campo a partir da questão de conceitualização e definição de republicanismo para que seja possível propormos aqui uma síntese. Por isso, importantes obras de cunho histórico e teórico só serão analisadas lateralmente e como suporte ao argumento central. Por exemplo, Republicanism, de Philip Pettit (1997), é um marco indispensável para os estudos contemporâneos na temática; entretanto, por sua proposição inovadora, o livro concede menos importância ao debate dentro do campo do que busca ele mesmo desenvolver suas próprias teorias. Diferentemente de Just Freedom, do mesmo Pettit (2014), no qual busca uma definição, produz uma interpretação sobre o republicanismo em claro diálogo com outras definições. Para uma revisão de república, republicanismo e similares em manuais, dicionários especializados e enciclopédias, ver: Falcão, 2019, p. 145-146, nota I. 
Diante disso, o presente artigo não objetiva uma revisão enciclopédia, histórica, nem mesmo tem qualquer pretensão de inovação teórica, histórica ou normativa. $\mathrm{O}$ que guiou o presente trabalho foi buscar recolher de pesquisas recentes justamente a questão basilar com a qual todos se defrontam quanto ao tema: o que é o republicanismo? Mas, antes disso, é preciso uma breve explanação sobre os diferentes modos de perscrutar o tema.

Desse ponto de vista, é preciso colocar em perspectiva crítica muitas das abordagens empregadas. Não é raro encontrarmos definiçóes de republicanismo pelas teorias que se lhe opóem. Dessa forma, o republicanismo é muitas vezes apresentado como aquilo que não é: ele não é monarquista, não é liberal, não é utilitarista etc. Mais grave ainda ocorre quando se conceitua república e republicanismo amparando-se em autores e sistemas filosóficos. Os casos emblemáticos de Bodin, Hobbes, William Paley, Rawls e Nozick servem de exemplo para isso. Há situaçóes, como veremos à frente, em que se define republicanismo pelo contrário do que defendem esses e outros autores. Não é preciso reconhecer qualquer contribuição deles para o republicanismo para identificar que uma definição negativa - o republicanismo como a negaçáo de algo - não se sustenta teoricamente ou significa reduzi-lo a uma resposta contextualizada de tal modo que, deve-se concluir, se essas teorias e autores não existissem, o republicanismo também não existiria, o que parece algo um tanto despropositado. Porque ele existiria em função e em oposição a algo já consolidado, sendo assim, uma antiteoria, o que só seria possível se ele não tivesse dimensão propositiva significativa. Todavia, o republicanismo é essencialmente propositivo.

Mas é claro que diferentes tradiçóes se desenvolvem em diálogo crítico umas com as outras, na medida em que se compreende, por exemplo, como um Harrington acentuou deliberadamente seu modelo republicano para chamar a atenção para suas críticas a Hobbes. A questão é que esse tipo de diálogo crítico está longe de ser exclusividade do republicanismo, tornando sua classificação por essa via indistinta dos demais percursos. Afinal, o liberalismo contratualista, por exemplo, tinha entre seus principais inimigos o direito divino dos reis e a natureza humana aristotélica típica da tradição escolástica.

Além disso, é bastante comum nesse tipo de estudo aparecerem incongruências evidentes, por exemplo, o fato de um conceito ser defendido por 
um autor geralmente classificado de republicano, mas o conceito não; e, inversamente, que um conceito que apareça em um autor geralmente não entendido como republicano deixe de ser. Trata-se, afinal, de um problema lógico que recorrentemente encontramos nos estudos mais generalistas sobre o republicanismo (e muitas outras tradiçóes e teorias políticas). Se um autor Xr é republicano e defende Yn, logo, Yn é parte do republicanismo; ou, se um conceito republicano Yr é defendido por um autor Xn, logo, o autor é republicano. Esse é um problema comum e já foi lembrado por J. C. Davis (2013) sobre seus perigos. Davis defende que toda forma de pensamento político que se conforme em uma "tradição" deve ser estudada com o cuidado de que não se produza nenhuma definição estritamente autoral nem conceitual (POCOCK, 1987, p. 329). Ele se refere às dificuldades do republicanismo em especial (HONOHAN, 2002, p. 5).

De fato, a relação entre sistemas teóricos e conceitos é particularmente espinhosa quando se trata de republicanismo, muitos dos conceitos são usados por autores claramente não republicanos, e até declaradamente monarquistas ou parte de tradiçóes ainda mais longínquas, e muitos republicanos defendem coisas que dificilmente se aceitariam de um republicano. Esse tipo de problema levou estudiosos consagrados a caírem na armadilha de ter que reconhecer que Locke, por exemplo, seja um republicano e náo um liberal, e Paine um antirrepublicano, por Pettit (2014, p. 24) e Pocock (2003, p. 575), respectivamente. Ou, no mundo francês, Saint Victor e Branthôme (2018) insistem na importância de uma "monarquia republicana” para tratar desse país desde, pelo menos, o século XIV. O caso de Rousseau, outro exemplo, é extremamente controverso, afinal, a vontade geral é o genuíno interesse público ou o totalitarismo de um pensamento metafísico? Não há aqui qualquer pretensão em responder essas questôes; mas, objetiva-se mostrar os argumentos a favor e contra cada uma das interpretaçóes de modo que a síntese aqui proposta se deixe ver.

Os argumentos de cunho tautológico devem ser evitados; mas, para isso, é preciso que se reconheça que o republicanismo habita inerentemente uma zona cinzenta ${ }^{7}$ Em geral, a aplicação da tautologia nesse tipo de

7 Empregamos a palavra tautologia e seus derivados não no sentido técnico dos estudos de lógica nem na simples redundância, mas a partir de um procedimento comum por meio do qual se entende que uma determinada coisa 
estudo acaba obscurecendo mais do que clareando os conceitos. Deve-se aceitar apenas por um pressuposto empírico, isto é, a recorrência da aparição de determinados conceitos e teorias em determinados autores e sistemas, os temas centrais a fim de testá-los não como sendo mais ou menos republicanos, pois isso suporia a existência de um e somente um republicanismo, mas como parte da diversidade dos republicanismos.

A outra ponta dessa dificuldade é exatamente encontrar republicanismos onde eles não existem, seja por ser indisponível, do ponto de vista da linguagem historicamente contextualizada, seja porque isso desloca a preocupação central de um determinado sistema teórico. Formulaçóes extremamente rígidas sobre o republicanismo, como dizemos de Pettit, levam a paradoxos de se verem obrigadas a reconhecer em Locke um republicano autêntico e Rousseau quase como um adversário. Na verdade, apenas pesquisas de caráter fortemente teleológico chegam a conclusóes similares. Se dissermos que Y é republicanismo e tudo que tiver Y será republicano, logo, Y é apenas a condição suficiente.

O caminho tentador é o meio-termo, e o mais seguro. Nem tanto que se pretenda engessar determinados conceitos no republicanismo nem o republicanismo em conceitos ou autores. $\mathrm{O}$ modo mais seguro de se fazer isso ainda é através da combinação dos critérios de necessidade e suficiência ${ }^{8}$. Partir axiomaticamente do silogismo de que, em termos republicanos, não há nada, nenhum conceito ou autor, que seja suficiente para definir o republicanismo ou, se há, ele é táo vazio de significado que se torna inócuo, é um esforço que mais ganha destaque nas pesquisas recentes.

pode ser entendida como tal se contiver determinada(s) característica(s). Aqui, entendemos essa aplicação da tautologia como uma estratégia retórica de apresentação do argumento, um modo procedimental de conferir validade a uma definição de republicanismo a partir de uma(s) característica(s).

8 Há casos paradigmáticos em que esse expediente, digamos, metodológico é aplicado ao republicanismo. Apenas para citar rapidamente alguns exemplos: Tenzer (1993, p. 24) afirma que o "respeito às leis é necessário, mas não suficiente", Baccelli (2003, p. xviii) que “[...] a divisão do poder e a sua articulação, em geral com o sistema de checks and balances e de vínculos institucionais que articulam o governo 'republicano', são uma condição necessária, mas não suficiente”; Maynor (2003, p. 58) cita que o poder recíproco entre indivíduos da liberdade como não dominação "pode ser visto como uma condição necessária, mas insuficiente para a autodeterminação [de cada um]". Hamel (2019, p. 84) questiona retoricamente se o "[...] império das leis aos quais os governos são submetidos é uma condição suficiente para proteger o direito natural à liberdade que possui cada homem?", sobretudo segundo Markell (2008). 
Por outro lado, existem "n" condiçôes necessárias para se dizer de uma doutrina republicana, e geralmente é sobre as relaçóes internas entre essas questôes que as pesquisas menos se debruçam, isso é, sobre seu agregado em diálogo com a teoria no momento de apresentar a síntese e responder à pergunta sobre o que seja o republicanismo. Não se deve pretender, obviamente, que o cumprimento de todas ou uma parcela qualquer dessas condiçóes seja efetivamente preciso para se dizer que algo ou alguém seja republicano. Nesse sentido, o republicanismo é uma doutrina cinzenta, indefinível peremptoriamente por si mesma, menos ainda a priori, mas sempre reconhecível, sobretudo, quando confrontada na teoria e na prática.

A despeito de todas as críticas plausíveis, foi Pettit (2014) o mais feliz ao afirmar que o republicanismo pode ser entendido como um GPS, isso é, sistema intelectual norteador para açóes e reflexóes em condições de modernidade. Responder à pergunta "o que é o republicanismo", na verdade, é uma construção inacabável e que sempre requer atualizaçóes, mas os fundamentos centrais podem oferecer esse GPS. Não precisamos concordar com Pettit sobre qual seja o direcionamento de seu GPS republicano, mas a metáfora é muito precisa. É evidente que Locke possui robustas características que qualquer pessoa com boa intenção reconheceria como republicanas e a mesma pessoa talvez dissesse horrores do republicanismo de Rousseau. O problema figura nas afirmaçóes taxativas: "se Y, logo X". Dependendo do ângulo de entrada sobre o que seja o republicanismo, Locke ou Rousseau podem, legitimamente, serem cada um mais ou menos republicano do que o outro. Ao invés de se afirmar a fórmula comprometedora de "se Y, logo X" ou "se X, logo Y", uma hipótese aqui levantada é que é mais produtivo afirmar que, se Y mais Y' mais Y” etc., a tendência é de uma aproximação com o republicanismo através de um conjunto de condiçóes que o norteiam.

Entretanto, essa abordagem tem um problema central. Também não devemos afirmar que o republicanismo seja somente um ideal normativo de ação ou moralidade, pois o republicanismo não se presta apenas ou fundamentalmente a um marco regulatório procedimental, preciso e distinguível. Por sua própria essência e história, o republicanismo aparece com uma dimensão prática muito evidente, realisticamente aplicável ao 
contexto em que se encontra. Daí que seja ele tão moldável, fluido e cinzento, diferentemente do que muitas vezes se pretende fazer com tradiçôes mais conhecidas.

Evidentemente que náo seria o caso aqui de distinguir, identificar e teorizar sobre cada uma dessas possíveis condiçôes, mas também não se pode silenciar por completo. Apenas a título de proposição inicial, que não desenvolveremos em toda sua magnitude, pode-se supor que o republicanismo necessita ser antiautoritário (em sua versão exclusivista antimonárquica ou pluralista, que aceita, em algum nível, uma figura assemelhada ao monarca), com um governo misto, império das leis, assentado nos conceitos de liberdade e igualdade em relação mútua (ou um viés mais claramente isonômico), e com alguma preocupação com a cidadania, participação ou virtude cívica (FALCÃO, 2019, p. 149-162). Pelo mesmo motivo, é preciso também que nenhuma dessas condiçóes seja suficiente, o que quer dizer que não basta um único desses princípios isoladamente, é preciso jogar luz sobre como eles interagem entre si em determinadas circunstâncias. Retomaremos a esses conceitos, não para defini-los, mas para usá-los como exemplo de abordagem para uma definição relativamente aberta, mas útil e compreensível.

Nesse ponto, é preciso estabelecer uma clareza um pouco maior sobre o objeto em tela; para isso, optamos por uma revisão bibliográfica de obras relativamente recentes que se debruçam sobre o tema. Com elas, argumentaremos que o republicanismo tem sido tratado ou como uma forma exclusivamente tautológica de definiçóes e conceitos ou meramente como uma reconstrução histórica; no mais das vezes, há casos em que ele acaba por ser reconhecido como algo com exclusividade conceitual e historicamente restrito.

\section{A suposta exceção francesa}

Dissemos acima que a maioria dos trabalhos que fitam definir ou que se pretendem introdutórios sobre republicanismo parte de uma perspectiva histórica, justamente pela dificuldade na agregação de conceitos formulados em situaçóes tão diversas e mesmo com fundamentos filosóficos díspares. Ocorre ainda um problema complementar. Além da dificuldade 
de unidade conceitual, geralmente essas introduções ou definiçôes partem de um determinado contexto nacional, historicamente estabelecido; por isso, acabam por se opor aos demais republicanismos. Tomemos alguns exemplos para clarear a questáo.

O livro de Juliette Grange (2008), intitulado L'idée de République, tem como objetivo central apresentar o que a autora chama de "ideia", a fim de afastar a percepção de que o republicanismo seja um sistema fechado, homogêneo e hermético. Porém, isso não a impediu de restringir seu objeto a um contexto muito particular: a terceira república francesa (1870-1940), diretamente inspirada no período revolucionário. Existem particularidades desse contexto que não se aplicam a outras expressóes do republicanismo na modernidade.

Para Grange, o republicanismo implica uma íntima relação com o socialismo, com a laicidade do Estado, com a forma institucional da república como necessária e restritivamente derivada de uma revoluçáo, com sua pujante distância para com o comunitarismo e o liberalismo, com o direito como forma de bem comum, com sua diferenciação da democracia, com a proximidade entre monarquia e autoritarismo, com sua preocupação social e com a noção de unidade política do povo. "Nosso objetivo aqui é de dialogar, mas também de diferenciar a tradição republicana francesa, de Rousseau a Jaurès" (GRANGE, 2008, p. 25, itálico original), da anglo-saxã, representada por Skinner, Pettit e Pocock. A autora é taxativa: "Sustentamos que a ideia de república e sua realidade política náo é o resultado do Iluminismo e da filosofia política moderna, mas é a obra do século XIX francês em sua referência à revolução" (GRANGE, 2008, p. 46, itálico original).

Ora, o que Grange faz não é muito diferente de afirmar que republicanismo é tudo aquilo que ocorreu, no âmbito das ideias, naquilo que historicamente se pode verificar durante a terceira república francesa e, como tal, seus conceitos fundamentais determinam o que seja o republicanismo. É claro que se poderia contra-argumentar essa perspectiva afirmando a importância de um Maquiavel, Harrington ou mesmo Saint-Just, da revolução americana e das recentes contribuiçóes ou, entrando por outro caminho, mencionando que há uma tradição republicana fortemente vinculada à religião civil, que a exclusividade antimonárquica é apenas uma página 
na história do pensamento, ou que a linguagem dos direitos se aproxima bem mais do liberalismo. Poder-se-ia também lembrar que o tema da liberdade é diminuído, ainda que ela o trate em compasso com a igualdade ou que o império das leis seja resultado, necessariamente, da supremacia do direito ou da justiça.

Grange não objetiva debater o republicanismo daquela França, mas afirmar que tudo que é republicanismo é oriundo daquela França. Seria despropositado mostrar as armadilhas que isso produz. Parece mais produtivo compreender seus argumentos pela lógica interna e, com isso, perceber que, no fundo, Grange cai na mesma tautologia que pretende criticar. Se a terceira república francesa é o republicanismo, tudo que deriva dela é republicano: estabelece-se um paradigma historicamente definido e, com isso, torna o debate e suas riquezas inutilizáveis. Parece evidente que o debate com as contribuiçóes anglo-saxãs objetiva contrariá-las em seus principais fundamentos, porque deixaram a França praticamente de fora da reconstituição histórica do pensamento político moderno ou porque inculcaram no republicanismo conceitos que à autora pareciam estranhos.

Ainda assim, Grange (2008) mantém os termos do antiautoritarismo (p. 28 e 31, 37, 47), o governo das leis, que se difere da common law (p. 29, 73), uma ideia de liberdade que associa indivíduo e coletividade (p. 46) que se opóe ao modelo anglo-saxão (p. 190-201), uma igualdade política desnaturalizada (p. 90), e alguma presença de virtude (p. 106-112) e da cidadania (p. 134-138). E chega a colocar com clareza uma passagem que corrobora com a embocadura de suficiência e necessidade acima aludidas: "A república não é procedimental. As instituições somente valem na medida em que experimentam essa vontade e não apenas por suas formas, elas são necessárias, mas não suficientes" (GRANGE, 2008, p. 38). É evidente que os procedimentos republicanos são inerentes e necessários ao republicanismo, mas não suficientes. Todo esse republicanismo gira em torno de direitos universais, diretamente atrelados a uma igualdade fundamental. Assim, Rousseau é a figura máxima, mas apenas se concretizaria como tal na medida em que o diálogo com o genebrino seja estendido ao longo do século XIX. Por fim, o livro tem por pano de fundo uma teoria dos direitos universalizáveis. Todos os termos tautológicos dessa definição 
francesa de republicanismo dependem de que os direitos coletivos estejam em constante ampliação e é isso que conforma a ideia de republicanismo.

Jean-Fabien Spitz tratou, pouco antes, do mesmo período, mas com uma abordagem inteiramente diferente. A obra cobre os principais personagens e pensadores da terceira república francesa a fim de mostrar que, diferentemente do que comumente se acredita, há uma continuidade entre o último período do momento maquiaveliano durante o século XVIII inglês e a França do seguinte. Para ele, a república é um projeto eminentemente moderno, no qual a cidadania e a igualdade regem as garantias individuais sustentadas nos direitos coletivos a partir da cultura revolucionária francesa. Essa cultura se inscreve em Rousseau e nos diálogos que foram travados posteriormente com ele, formatando um "republicanismo euro-atlântico" (SPITZ, 2005, p. 14) de tal modo que a liberdade e a igualdade não possam ser pensadas separadamente. Contudo, isso não é necessariamente antiliberal, pelo contrário, criticando Furet, Spitz afirma a centralidade do conceito de liberdade no seio do republicanismo, em condições de modernidade.

Em primeiro lugar, a cultura política republicana assume que o conceito de igualdade é interno ao conceito de liberdade, e que a liberação dos indivíduos se passa pelo acesso à condição igualitária de cidadão, por sua integração em um todo cívico onde eles são uniformemente submetidos à lei. (SPITZ, 2005, p. 17).

Isso significa que a integração liberdade e igualdade em um universo individualista moderno exige um arcabouço de direitos garantidos pelo Estado, a fim de que as desigualdades existentes sejam legítimas (SPITZ, 2005, p. 31-35).

Essa instigante contribuição de Spitz, ainda que se dedique a autores e personagens de destaque daquela França, tem por base uma contribuição teórica eminente. $\mathrm{O}$ republicanismo conecta as relaçóes de liberdade e igualdade de um modo satisfatório e avançado, dada a complexidade das sociedades modernas, o que significa que a realidade concreta na qual ele se apresenta é respondida de modo eficaz pela ação do Estado. Não surpreende, portanto, que o liberalismo seja um "herdeiro" do republicanismo, como já tinha dito Viroli, mas que se mostrou ineficiente para responder com a mesma profundidade, porque eivado de pressupostos individualistas 
e mercadológicos, sustentados em uma lei da natureza ou direito natural. Por seu lado, Spitz segue Pettit na definição de liberdade como não dominação, mas vai além ao afirmar que ela nada mais é do que "um outro nome para interesse geral" (SPITZ, 2005, p. 40). Temos, novamente, uma análise francesa que se centra no Estado e no direito, mas que, nesse caso, não se opóe ao indivíduo, para garantir a igualdade de chances.

Uma das propostas mais interessantes e audaciosas de Spitz ao longo do livro reside em rejeitar implicitamente as definiçóes tautológicas ou $a$ posteriori de republicanismo. Ao contrário, ele pretende buscar aspectos complementares entre diferentes filosofias políticas e conceitos de tal maneira que o todo republicano se deixe ver. Assim, ele acaba por incorrer em um problema inverso: ora, se não se pode afirmar que tudo que contiver Y, Y', Y” etc. é republicano, mas tudo que é republicano é complementar entre inúmeros Ys, não há como existir uma pluralidade de republicanismos. A maneira pela qual estamos mostrando o argumento está radicalizada, Spitz não chega ao ponto de afirmar que as complementaridades devam ser de tal ordem que produzam uma única filosofia política coesa, o que resta, portanto, é uma massa cinzenta de ideias mais ou menos conexas. A conexão, afirma-se subliminarmente ao longo da obra, só pode ser feita pelo contexto, qual seja, a recepção e o desenvolvimento durante a terceira república francesa do momento maquiaveliano.

Para fechar o caso, é necessário dizer que Spitz debate, lateralmente é verdade, os termos complementares, quais sejam, a virtude, a cidadania e a participação, o governo misto e o império das leis, de modo que não apenas mostra uma coerência na continuidade, mas também um caráter "filosoficamente normativo" (SPITZ, 2005, p. 112) e atual. O que emerge, entretanto, da contribuição do autor é uma teoria da justiça bem fundamentada em linha de consecução interpretativa com uma filosofia da história pautada no progresso humano e universal, uma concepção de nação a partir de metáforas organicistas e uma forte revivescência do contrato social.

Atacada diretamente por Grange (2008, p. 122) por sua dimensão eminentemente conservadora, Blandine Kriegel (1998) sustenta, de modo bastante isolado nessa literatura, que o republicanismo seja consequên- 
cia direta do monarquismo, a partir do conceito de soberania e o estabelecimento do Estado de direitos, fincados na ideia de unidade nacional. Seu argumento fundamental passa ao largo de tudo o que discutimos até aqui e de tudo que se seguirá à frente.

Com o surgimento dos Estados modernos e particularmente com o desenvolvimento do conceito de soberania com Bodin no século XVI, emerge uma teoria que se opóe frontalmente ao domínio imperial e senhorial caracteristicamente medieval. A legitimidade das ordens do governante começa a se assentar no direito e, assim, torna o uso da força inválido. Nesse sentido, argumenta Kriegel (1998, p. 18), o Estado moderno é concernente à república em oposição ao império, domínio pautado na força militar e equivalente ao comando privado, que, em grande medida, se realiza através de sistemas corporativistas nos quais os estamentos sociais suplantam as classes, as funções sociais são determinadas pelo locus de nascimento e as garantias individuais são inexistentes (KRIEGEL, 1998, p. 77). Por mais surpreendente que possa parecer, o Estado de direitos republicano, ainda se sustenta, segundo Kriegel (1998), em algum "nível de igualdade fundamental” (p. 198), em "divisão dos poderes" (p. 150), na "cidadania" (p. 230) e na "liberdade" (p. 329).

O ponto-chave dessa leitura bem heterodoxa da formação moderna do republicanismo, que destaca pensadores absolutistas em detrimento de democratas, reside no debate que sobreviveria até o século XX entre a funçáo do Estado como norma legal e aquela como vontade ou determinaçáo. O primeiro se refere a uma doutrina legalista cuja norma jurídica assentada no Estado é necessariamente referente ao processo histórico e normativamente construído; não há, nesse caso, nenhum fundamento das leis que não em uma conquista civilizatória (KRIEGEL, 1998, p. 126). Assim, a política é separada da guerra, o direito da força, as açóes governamentais são realizadas por determinação prévia, em suma, o Estado é absoluto mas limitado; na esfera em que se encontra, age com toda a força possível, mas não pode ultrapassar alguns limites, como o da segurança individual ou da propriedade. No segundo caso, trata-se da inscrição da política no vocabulário da guerra, do permanente conflito físico no qual todo objetivo é a aniquilação do inimigo cujo ponto alto, historicamente falando, é a 
Alemanha nazista. Mas a questão de fundo, posta exemplarmente no conhecido debate Kelsen-Schmitt, pode ser lida como a atualização do problema da relação entre governo das leis ou dos homens. Kriegel (1998, p. 68) acusa a bibliografia predominante francesa de germanismo historiográfico pelo fato de que, a partir da terceira república, aceitaram os intelectuais daquele país que a república moderna era derivada da Idade Média.

Essa questão foi respondida de muitas maneiras e com diferentes objetivos, destacamos aqui apenas aqueles que mais marcaram os republicanismos. $\mathrm{O}$ primeiro ponto que se deve ter em mente quando se avalia a possibilidade do império das leis é não as tomar como um ato unilateral do governante em relação ao governado, mas como uma autodeterminação coletiva, um conjunto de regras às quais todos aqueles que participaram de sua formulação estão igualmente submetidos. Legislar não é um ato do governante em direçáo ao governado, mas um ato de soberania coletivamente compartilhada. Novamente, vemos aqui o republicanismo, para responder a um problema, esbarrar em outros de seus conceitos. Não se pode pensar o império da lei desvinculado do autogoverno coletivo, e esse é um ponto de relativo consenso entre os distintos republicanismos. Por isso, torna-se algo um tanto bizarro identificar em Bodin a origem do republicanismo moderno, como faz Kriegel, e não nas formulações, por exemplo, maquiavelianas para ficarmos no mesmo século, de autodeterminação coletiva.

Parece claro que, de um lado, o republicanismo com a ascensão dos Estados modernos não pode dispensar a soberania (ARAÚJO, 2014); por outro lado, não é o fato de existir Estado moderno que seja republicano. Aceitar essa última máxima é esvaziar tanto o republicanismo de significado que ele perde inteiramente qualquer sentido. Se o Estado moderno se formou contrariamente à arbitrariedade medieval, esse é apenas um ponto de contato com o Estado de direito republicano, mas náo sua integralidade. De fato, as leis passam a ter um fiador desconhecido do mundo antigo e medieval: o Estado moderno. Nesse sentido, o republicanismo necessitou articular o conceito de soberania com o de autodeterminação coletiva e, para isso, mobilizou a cidadania e a isonomia. A partir de então, o problema se tornou claro em compatibilizar a soberania dos Estados modernos com o autogoverno oriundo dos antigos. O que os primeiros teóricos do 
Estado moderno, com o devido destaque para Bodin e Hobbes, não atentavam era para uma forma de soberania que não dividisse soberanos e súditos peremptoriamente (KRIEGL, 1998, p. 98-99).

De algum modo, toda essa bibliografia francesa tem claras dívidas para com Claude Nicolet ${ }^{9}$, que sustentou um republicanismo francês eminentemente contraditório em suas bases, avesso à tradição anglo-saxã desde ao menos a revolução ${ }^{10}$. Um ponto inescapável dessas leituras é que esse republicanismo, se é que a tese da exceção deve ser ainda hoje sustentada, reside no universo dos direitos e que, por isso mesmo, se aproxima em termos jurídicos do liberalismo e em termos sociais do socialismo. Talvez o melhor exemplo desse exclusivismo francês seja o volumoso manual de Victor e Branthôme (2018). Nele, chegam a colocar em dúvida o emprego de "tradição republicana", uma vez que o republicanismo se origina modernamente com a revolução, afinal a "tese anglo-saxã ignora totalmente o debate francês" (VICTOR; BANTHÔME, 2018, p. 6, p. 41, 157 e 297). Parte-se, então, de um quadro analítico de uma sensibilidade liberal, afeita ao governo misto e a limitação do poder, da sensibilidade jacobina, originada na democracia de Rousseau, da sensibilidade plebeia, diretamente inspirada no materialismo e na luta de classes, e a sensibilidade conservadora, definida a partir da restauração. Ainda que dialogue com a bibliografia anglo-saxá, ressaltando seu esquecimento francês, o livro reforça a ideia de exceção daquele país. Essa reconstrução se centra no governo misto e, com ele, os limites do poder estatal, e no antimonarquismo, que, agora sim, conferiria o caráter específico do republicanismo, mas também se refere aos outros termos, de tal modo que essa síntese apresenta mais um percurso do pensamento político que teve lugar na França do que visa a um tratamento exclusivo do republicanismo.

9 Provavelmente o exemplo mais claro dessa dívida intelectual seja Tenzer ( 1993) em seu livro introdutório.

10 Não se trata aqui, evidentemente, de uma bibliografia produzida na França ou em idioma francês, mas daquela que busca a exceção francesa ou a integração francesa na definição e formação do pensamento republicano moderno. Um excelente contraexemplo disso é o livro introdutório e primoroso de Serge Audier (2004). Nele, o autor passa em revista a história do republicanismo moderno em concomitância com o surgimento dos conceitos fundamentais, que aludimos acima, e apresenta diversas contradições internas, como o modelo conflitivo maquiaveliano em oposição ao harmonioso ciceroniano, a liberdade e o comando da lei, o bem comum e os direitos individuais, em claro diálogo com a bibliografia anglo-saxã e a francesa. 
Até aqui, dedicamo-nos aos estudos que se concentram na França, sua suposta exceção e o diálogo com a tradição anglo-saxã. A tautologia que apontamos acima, com a exceção que comentamos de Spitz, permanece válida, ou seja, republicanismo é aquilo que possui as características fundamentais do experimento da terceira república francesa, fundamentalmente, sustentado na ideia de direitos coletivos e individuais, o que reduz a importância relativa do conceito, por exemplo, de liberdade.

Mas essa tautologia é historicamente orientada, ou seja, ocorre a combinação de uma definiçáo historicamente restritiva com os marcos centrais de um conjunto de conceitos daquela mesma experiência. A vantagem mais evidente dessas abordagens é que se torna mais palpável um programa bem definido para o republicanismo atual, quase sempre, sustentado na universalidade dos direitos e na sua legitimidade expansionista pelo mundo não Europeu (TENZER, 1993, p. 114-116). Em paralelo, há outro conjunto de pesquisas, na qual Audier (2004) se insere, que busca explicar o que seja o republicanismo com uma reconstituição histórica. Não nos referimos aqui às alardeadas publicaçóes de Pocock, Skinner e seus seguidores, mas àquelas que objetivam uma definiçáo propriamente de republicanismo que, possivelmente de modo estratégico, fogem das definiçóes tautológicas, mas perscrutam um resumo.

\section{A estratégia histórica}

Se lermos com atenção o Republicanism, de Maurizio Viroli (2002), veremos o esforço corrente de reconstrução histórica do percurso republicano. Mas essa história é inteiramente diferente daquela francesa. Inicia-se no humanismo italiano, passa pelas guerras civis inglesas, a revolução americana e chega ao mundo contemporâneo. Claramente, seu objetivo reside em unir a proposta histórica de Pocock com a teoria da liberdade de Pettit, com uma forte entrada na tradicional ideia de bem comum, característica do republicanismo ciceroniano ou do humanismo cívico. Em um de seus pontos mais originais, o autor advoga que o liberalismo e a democracia não são absolutamente refratários ao republicanismo, pelo contrário, são seus verdadeiros e legítimos herdeiros no mundo contemporâneo (VIROLI, 2002, p. 6-7, 33, 43 e 58). Viroli sequer menciona o 
século XIX francês e menos ainda a terceira república, apenas tangencia aquele país quando fala de Montesquieu e de Rousseau"'.

Um dos pontos de destaque da contribuição de Viroli é a retomada do sentido do patriotismo que, segundo o autor, se difere dos nacionalismos. Ele sustenta o ponto a partir de personagens italianos do século XIX, como Carlo Pisacane e Giuseppe Mazzini; com isso, chama a atenção para um grupo de autores e um contexto pouco estudado pelas pesquisas sobre republicanismo. $\mathrm{O}$ sentido desse patriotismo se confunde com o de autogoverno.

Viroli (2002) ainda destaca o papel do "governo misto com divisão de poderes" (p. 5-6), império da lei (p. 7-9), a "virtude” (p. 12, 69-78), "liberdade com participação instrumental” (p. 11 e 66). Por trás dessa empreitada, há uma contrariedade latente: ora, o humanismo cívico, aquele cujas bases se fundam no estoicismo ou em Cícero, confere à participação um valor eminentemente intrínseco em oposição à vida contemplativa medieval. Trata-se, afinal, de uma reorientação do que seja o humanismo cívico ou uma discordância de fundo com o papel da representação política no republicanismo neorromano? Viroli não responde a essa questáo, possivelmente porque seu anseio de unir reconstruçáo histórica com conceitos-chave acaba por se deparar com problemas insolúveis sob esse ponto de vista. De fato, ele praticamente escapa de qualquer entrada tautológica para a compreensão de republicanismo; mas, com isso, acaba tornando-o de tal modo fluido que se confunde com a democracia e o liberalismo contemporâneos.

Mais radical do que a versão de Viroli, é a proposta de Kalyvas e Katznelson (2018, p. 4) sobre o "falso antagonismo" entre republicanismo e

II A ideia de que o século XIX e a primeira metade do XX não têm contribuições significativas ao republicanismo não é original de Viroli. Skinner (1998, p. 80) já tinha indicado que esse período foi hegemonizado pelo utilitarismo liberal e pelo positivismo. Anos depois, o próprio Pettit (2014, p. 13-22) nomeou o período de "eclipse do republicanismo", como se suas manifestações fossem menores. Grange (2008, p. 173-174), seguindo Maurice Agulhon, relata algo semelhante durante o mesmo período, mas se refere apenas à França, uma vez que, segundo a autora, a ideia de república se tornou esvaziada o bastante para se confundir com a de Estado, permitindo, portanto, uma "direita republicana", pressupondo que o republicanismo seja ou deva ser necessariamente de esquerda. Brugger (1999, p. 67-73) fala de um "eclipse da virtude" ao longo do século XVIII pela ascensão do utilitarismo e Saint Victor e Branthôme (2018, p. 19 e 96) de "eclipse" durante a ascensão intelectual do marxismo. 
liberalismo, já que "o liberalismo não é externo à história do republicanismo". O que é particularmente interessante nessa abordagem reside no fato de o diálogo ser travado dentro do contexto anglo-saxão, embora tenha por objeto central a ilustração escocesa e a França de inícios do século XIX. Como esperado, o conceito de liberdade e o debate também com os comunitaristas estão presentes em conformação com o mundo moderno (KALYVAS; KATZNELSON, 2018, p. 29-33, 150, 160).

Bill Brugger (1999) propóe uma chave semelhante, com termos diferentes. Ele fita unir teoria e contexto em quatro tipos ideais - história, virtude, soberania popular e liberdade - em quatro momentos - republicanismo moderno (italiano e inglês), iluminista (francês e escocês), a revolução americana e a contribuiçáo contemporânea. Esses quatro tipos ideais se bifurcam em duas versóes do republicanismo: 1) centrado na virtude, na ação, na pessoa, na qualidade do agente e 2) centrado na instituição, na representação, no virtual, na razão abstrata e imparcial.

A embocadura weberiana de "tipos ideais" (BRUGGER, 1999, p. 17) orientada a partir de diferentes contextos escapa, por um lado, da tautologia da definição; por outro, torna-se novamente presa da definição de liberdade como não dominação. No anseio contrário ao de Viroli, Brugger advoga distinçóes fundamentais entre republicanismo e a democracia bem como com o liberalismo e comunitarismo e, assim, tangencia o problema exposto acima de se definir republicanismo pela negativa. O republicanismo náo é comunitário nem democrata pela sustentação de um Estado moralmente neutro e pela participação como meio (BRUGGER, 1999, p. 12-13) e não é liberal pela distinção do conceito de liberdade (BRUGGER, 1999, p. 2-8, 33, 39-44).

Com uma entrada fortemente filosófica, incluindo aí campos da filosofia natural e da epistemologia pouco debatidos pelos estudiosos do republicanismo, Brugger (1999) insere seu modelo histórico-ideal de tal modo que ele seja capaz de propor "alternativas ao debate liberal-comunitário" (p. 181). Novamente, ele aceita que o "governo misto" (p. 20, 86), "império da lei" (p. 46, 96, 139), a "rejeição à autocracia” (p. 65), e "defesa da igualdade" (p. 74, 140) complementam o quadro ideal-tipo ${ }^{12}$.

12 Igualmente com uma entrada histórico-conceitual, Thomas Maissen (2019) pretende superar a polissemia da palavra e dos usos de "republicanismo" por um enquadramento que sintetiza o republicanismo moderno em 
Dentre as obras de síntese do republicanismo, Matrizes do Republicanismo é uma das poucas produzidas coletivamente. Sérgio Cardoso, Helton Adverse, Alberto Barros, Newton Bignotto e Heloísa Starling escrevem, cada um, um capítulo sobre a matriz romana, a italiano, a inglesa, a francesa e a americana, respectivamente, sob a organização de Bignotto (2013). O livro como um todo reforça os termos da liberdade e da igualdade, do império das leis, do governo misto, do antiautoritarismo, da virtude e participaçáo à luz de cada contexto e com destaque para diferentes autores e personagens. Há um pressuposto, por um lado, de uma linguagem comum entre as matrizes; por outro, no fato de que elas se diferem devido às circunstâncias de tal modo que cada matriz se apresente com certa unidade interna relativamente maior do que entre tradiçóes que perpassam os contextos ${ }^{13}$.

Ainda dentro da produção nacional, é importante destacar o mais recente Dicionário da República: 51 textos críticos, escrito por dezenas de autores de diferentes áreas das humanidades e organizado por Lilia Schwarcz e Heloisa Starling (2019). A obra perpassa diversos conceitos, as matrizes referenciadas acima e experiências históricas brasileiras. Uma vantagem para os estudos introdutórios é que os textos podem ser lidos separadamente, mas, justamente por ser uma obra coletiva, as concepçóes e formas de entrada são muito diversas e isso caracteriza bem a riqueza do campo republicano. Dentre os conceitos centrais do republicanismo aqui apontados, todos eles estão presentes na publicação. E mais: com relação ao antiautoritarismo e a cidadania, por exemplo, há pelo menos três e dois verbetes, respectivamente, que tratam diretamente de cada tema.

uma experiência cumulativa que sustenta diferentes inflexões teórico-conceituais, como do governo misto para divisão dos poderes, da separação entre regimes bons e corrompidos para a ideia de soberania, das pequenas cidades para as grandes federações, da participação à representação, da virtude cívica ao direito igualitário, da historicidade cíclica ao ideal de progresso. Esses termos, intercambiados pelas experiências e teorias, conformariam diferentes tradições republicanas.

13 Um esforço contrário fora feito por Marco Geuna (1998) argumentando por linhas de continuidade teórica em contextos diferentes. A cada um desses pontos, Geuna nomeia de família: uma maquiaveliana, centrada no conflito político e na unidade do poder, outra harmoniosa, voltada para uma perspectiva ciceroniana; uma origem aristotélica e outra romana; uma centrada na lei e outra na virtude. Cada família pode ser percorrida nos diferentes contextos Assim, ocorrerá um entendimento do republicanismo como forma de governo e modo de governar, como duas maneiras de entender a tradição, uma por um caminho mais formalista e institucional e outra por um comportamento ético principalmente dos governantes (FALCÃO, 20I3). 
De todo esse quadro com o qual estamos nos propondo a dialogar, o recente livro de Rachel Hammersley (2020) é o mais completo. Ainda que seus objetivos declarados sejam os de introduzir o leitor no universo do republicanismo, tal como muitos dos outros livros, a autora opta por um paradigma que até então era quase exclusividade de manuais e enciclopédias de teoria política: a reconstituição histórica. Mas isso produz uma dificuldade adicional, qual seja: "o que se destacar como história do republicanismo e do pensamento republicano?"; em seguida, dentro dessa história, "quais seriam os seus conceitos fundamentais?".

Dois termos devem ser considerados centrais aqui. O primeiro é a constante necessidade de Hammersley colocar em destaque o tema do bem comum em contato com as diferentes arquiteturas constitucionais. $\mathrm{O}$ segundo é a inovadora expressão dada aos símbolos, à iconografia e ao mercado editorial que percorre essa história, o que, diga-se, já estava presente no Dicionário da República.

Ela opta por um percurso que prioriza o debate sobre as formas de governo e o antimonarquismo ou exclusivismo republicano (HAMMERSLEY, 2020, p. 4, 137), o governo misto, a soberania, a religiáo civil, império da lei, a liberdade e a virtude (HAMMERSLEY, 2020, p. 5-14, 44, $46,125)$. Com grande sagacidade, a autora insiste ao longo da obra que o republicanismo é uma tradição de tal monta heterogênea e fluida que responde a problemas diferentes em contextos diferentes sob essas insígnias conceituais. Mesclando comentários a autores e a movimentos políticos, Hammersley passa em vista da antiguidade greco-romana aos debates contemporâneos. Difere-se, entretanto, das perspectivas anglo-saxãs ao inserir o século XIX francês, americano, inglês e italiano a partir de alguns pontos de inflexão: a inserção do trabalho como categoria relevante, a transição do debate entre república e monarquia para república e liberalismo, o surgimento de movimentos transnacionais como o de mulheres e trabalhadores, e sua consequente popularizaçáo. Num claro esforço de unir a consolidada bibliografia ítalo-atlântica com aquela francesa - iniciado com os trabalhos dos anos 1990 de Jean-Fabien Spitz -, Hammersley encerra o livro com uma análise das contribuiçóes contemporâneas, historiográficas e teóricas, e conclui que esse republicanismo atual é sustentado na igualdade, 
na liberdade, na deliberação popular e na virtude cívica (HAMMERSLEY, 2020, p. 206-207).

É claro que uma obra assim, e dados seus objetivos francamente introdutórios, é repleta de limitaçóes. Mas, ao contrário das estratégias histórico-conceituais de Viroli e Brugger (com os quais ela pouco dialoga), o percurso é amplo o suficiente para cobrir diversos temas e, com isso, fugir por completo de qualquer tautologia. Entretanto, como ocorre com inúmeros manuais, essa história pode soar arbitrária. Ora, "por que inserir a Polônia e a Irlanda, por exemplo, e silenciar sobre a proclamação da república espanhola de 1873 ou a portuguesa de 1910, uma vez que ela se dispóe a tratar do mesmo período europeu e já há uma importante bibliografia sobre o tema?”. Nesses casos, as opçóes devem ser feitas; contudo, o que parece problemático é a falta de justificativas para elas. $\mathrm{Na}$ verdade, a estratégia por uma explicação exclusivamente histórica dificilmente seria capaz de fugir do problema de deixar de fora experiências particulares ${ }^{14}$.

\section{Um republicanismo analítico-normativo?}

Dentre as obras de síntese mais destacadas, algumas não visam à recuperação de uma nação ou de contexto específico, nem à adequação entre conceito e acúmulo histórico, nem diferentes formas de classificar o republicanismo, nem a exclusiva reconstituição histórica, mas, sim, definir, a partir de um ou de alguns conceitos fundamentais, o republicanismo, que, ainda que se refira à tradição, não lhe é indispensável.

Em Critica del repubblicanesimo, Luca Baccelli (2003) orienta o republicanismo para um diálogo com as principais filosofias políticas contemporâneas. Longe de ser uma obra de divulgação ou introdução, ao contrário, supóe um razoável conhecimento prévio do leitor e objetiva aprofundar criticamente o estado das artes do republicanismo contemporâneo. $\mathrm{O}$ autor se centra nas instituiçóes atuais, em importante correspondência com

I4 As vertentes que insistem na dicotomia entre antigos e modernos, sobretudo de inspiração straussiana, a qual não abordaremos em detalhes, sugerem a irrelevância das diferentes classificações de republicanismos, de um ponto de vista histórico, porque, em regra, ele é completamente subsumido à modernidade liberal pela sobreposição do tema da liberdade em relação à virtude dos antigos. Para uma separação entre republicanismo antigo e moderno fora desse escopo, conforme Domènech, 2009. 
organismos internacionais e o papel determinante da globalização (BACCELLI, 2003, p. vii-xiii) ao mesmo tempo em que debate com os diferentes sistemas jurídicos não apenas do mundo ocidental (BACCELLI, 2003, p. ix-xix). O comunitarismo e o liberalismo contemporâneos são teorias fundamentais para Baccelli, não necessariamente pela herança republicana a favor ou contra, mas pelo entendimento do que seja o republicanismo de hoje, em contraste com o tema da natureza humana para o primeiro e do contratualismo individualista para o segundo.

O tema primordial é saber se e como o republicanismo é capaz de responder às questôes centrais dos problemas políticos do século XXI em grau de competência equiparado a outras filosofias. A resposta não é trivial, nem mesmo seria útil buscar aqui resumi-la, mas, como o título indica, a crítica do republicanismo faz crer em muitos potenciais se, e somente se, estiver em diálogo com a filosofia contemporânea. Temas como o realismo político, a razão de Estado e a universalidade dos direitos são os termos que conduzem sua análise sobre o republicanismo. De fato, ele pretende conduzir uma apreensão crítica de conceitos centrais do republicanismo e as possíveis respostas, muitas delas mais bem feitas por outras formas de pensamento. Questiona-se, assim, a própria validade de se creditar ao republicanismo alguma contribuição eminentemente singular.

Náo obstante a crítica, os temas centrais se repetem em Baccelli (2003): “o governo misto" e a "cidadania" (p. xx, 45-52), a "liberdade" (p. xxii, 99-102), “o governo das leis" (p. 116-133), a "igualdade” (p. xxiv), "constitucionalismo" (p. 10), "autogoverno" (p. 39). A partir do século XVIII, o republicanismo se bifurcou em dois grupos com o federalismo norte-americano: aqueles dos interesses e os do bem comum. Subsumidos a esse quadro, é possível, completa Baccelli (2003, p. 16), elencar outras oposiçóes: aristotelismo e neorromano, política como fim e política como meio, liberdade positiva e liberdade de domínio, concórdia e conflito. Ressalta-se que o quadro classificatório aqui está submetido a uma análise conceitual dos termos liberais e comunitários.

No mesmo ano e com objetivos similares, John Maynor (2003) apresenta os dilemas do republicanismo também em debate com o comunitarismo e o liberalismo (MAYNOR, 2003, p. 10-22). Retirando exemplos 
do quotidiano, a fim de ilustrar os problemas tratados, o autor critica duramente a definição de republicanismo pela simples extrapolação do ideal antimonárquico, o que, em condiçóes contemporâneas, diz pouco sobre uma agenda pública. Por isso, ele defende, literalmente, o emprego plural de republicanismos (MAYNOR, 2003, p. 4), algo que parece tentador. O ponto central do livro é o de radicalizar o argumento, originalmente elaborado por Pettit, de liberdade como não dominação em condiçôes em que se possam responder a demandas de grupos minoritários, de reconhecimento e de cidadania (MAYNOR, 2003, p. 138).

Ainda que muitos detalhes devam ser apontados nessa obra, como a extrapolação acrítica do conflito maquiaveiano para o mundo de hoje, conforme Maynor (2003), cabe destacar: a "presença do governo da lei" (p. 13, p. 41), a "liberdade" (p. 14-24), a "participação e cidadania" (p. 25-30), uma "virtude instrumental" (p. 69-76), uma forma institucional (p. 158-160). O republicanismo, assim, se difere do liberalismo por valores e ideais, pois, caso contrário, seria apenas um braço dele.

Temos aqui dois problemas de relevo: 1) ao afirmar, por exemplo, que Maquiavel possui uma "concepção alternativa de liberdade" (MAYNOR, 2003, p. 31), Maynor não identifica no contexto em relação a qual concepção a de Maquiavel é alternativa (MAYNOR, 2003, p. 121-123); 2) o republicanismo é aquilo que se difere do liberalismo e do comunitarismo, caindo no problema de uma antiteoria. Mas o destaque que ele concede ao tema da educação vai bem além de um resgate de sua importância na história do pensamento republicano (MAYNOR, 2003, p. 180-192). Ele sustenta a ideia, no mais das vezes comum em teorias democráticas, de que não é possível que um conjunto de valores seja sustentado sem que sejam desenvolvidos e compartilhados.

Pettit (2014), no livro já citado Just Freedom, tem um problema diverso dos demais. Em seu esforço de divulgação, ele não comete, propositalmente ou não, nenhuma descontinuidade interpretativa do republicanismo, não se apega a um contexto nacional específico, mas a um fundamento: o conceito de liberdade. Pettit, quando apresenta sua versão republicana, não separa aquilo que é ponto nodal - e quiçá exclusivo - em sua própria contribuição teórica daquilo que ocorreu em suas diferentes manifestaçóes 
na história do pensamento republicano. Possivelmente seja essa contribuição a mais poderosa e mais tautológica. Poder-se-ia quase que afirmar desse livro que aquilo que é republicanismo é aquilo que Pettit formulou como sendo o republicanismo, particularmente em obras anteriores; no entanto, o fato de esse livro ter sido escrito por Pettit não diz nada sobre isso. Mas, é preciso lembrar: se cometesse alguma desonestidade intelectual, ele esconderia a sua contribuiçáo. De fato, ele é claro quanto à sua posição já desde Republicanism de 1997, quando afirma que, ao encontrar contradiçóes entre a história e a teoria, deve o leitor seguir a segunda.

Náo resumiremos seu argumento aqui, o que nos interessa é sua definição do que seja o republicanismo. Mas é preciso ter em mente que Pettit está entre as figuras mais importantes do republicanismo contemporâneo e dificilmente isso não afetaria a sua própria obra de divulgação e resumo. O republicanismo, desse modo, é - sobretudo em sua versão mais radical do Just Freedom - a defesa do conceito de liberdade como não dominação. Nesse ponto, a tautologia se deixa ver por completo: ora, se a definição $a$ posteriori dos conceitos e tradiçóes deve ser feita mediante um único conceito sistematizador e agregador dos demais e de toda a teoria, os paroxismos anunciados acima se tornam inevitáveis (FALCÃO, 2017).

Complete-se o quadro analítico da obra com o detalhado debate com os liberalismos, aos quais Pettit (2014, p. 19-23) se refere como clássico, moderno e contemporâneo ou constitucional. Nesse esforço de resumir, republicanismo e liberalismos se afastam ou se aproximam mediante apenas o conceito de liberdade. E nota-se que, nessa leitura, a tradição liberal é entendida no plural e o republicanismo no singular; porém, o que geralmente ocorre é o contrário ou ambas são entendidas no plural. As diferenças do que ele chama de republicanismo ateniense, nas figuras de Hannah Arendt, Alasdair MacIntyre, Michael Sandel e Charles Taylor, igualmente se fazem pelo conceito de liberdade. Portanto, além de uma dimensão normativa que propóe um conceito de liberdade muito bem assentado, o neorrepublicanismo de Pettit se define em oposição a outras tradiçóes e teorias. É claro que seria errôneo afirmar que o neorrepublicanismo é apenas uma teoria contrária a outras, mas isso ser parte da sua própria definição é algo sintomático. O Just Freedom é excelente para apresentar sua própria teoria, mas é bastante insuficiente sobre outras interpretaçôes. 
Uma consequência dessa embocadura - de sintetizar o republicanismo por um conceito - é que ela pode ser reproduzida para outros conceitos. Ainda que esse náo tenha sido uma proposta frequente, é possível supor uma definiçáo de republicanismo, por exemplo, a partir do exclusivismo monárquico (DZELZAINIS, 2002; HANKINS, 2010; WOOTTON, 1994), ou seja, todos os que se opóem a qualquer forma de governo de um e à hereditariedade ou, resumidamente, a critérios inatos de legitimaçáo do comando político, seriam republicanos. Ou, ainda, se definirmos o republicanismo como algo sustentado no conflito (BALESTRIERI, 2010), tudo que se advoga contra o conflito é náo republicano. $\mathrm{O}$ mesmo se repete para o governo misto, a virtude, a cidadania etc.

Skinner (1998, 2002b), por exemplo, parece estar de acordo que uma teoria republicana deve ser antimonárquica, mas que há monarquias, moderadas e temperadas, que absorvem os ideais republicanos de governo misto, autogoverno e liberdade. Na verdade, essa é uma aplicaçáo crítica e conscientemente restritiva da definição de republicanismo sem tautologia. Nesse caso, as diferenças entre Pettit e Skinner ajudam muito a esclarecer o ponto. Se, para Pettit, republicanismo é fundamentalmente aquilo que defende a liberdade como não dominação, a potência normativa de seu argumento perde em riqueza e diversidade teórica. O que é algo bastante compreensível, porque seu projeto envolve a constituição de um sistema intelectual analiticamente bem assentado e diretamente preocupado com as democracias contemporâneas. $\mathrm{O}$ questionamento fundamental que deve ser feito à importante contribuição de Pettit é menos em respeito à validade teórica de suas colocaçôes e mais sobre a possibilidade de afirmar que sua teoria da liberdade seja exclusividade republicana. Ele próprio parece concordar com isso ao dizer que sua teoria talvez seja mais bem descrita como uma tradição de "civismo" (PETTIT, 2014, p. 211) do que propriamente republicana ${ }^{15}$.

Para encerrar o ponto, uma frase de Skinner é bem elucidativa: "O nervo da teoria republicana pode ser expresso dizendo que ela desconecta

15 Ainda entre aqueles que fitam uma síntese a partir de conceitos bem estabelecidos, Honohan (2002) sugere uma tripla classificação: a história do pensamento político republicano, a teoria constitucional-legal e a teoria política normativa. E não nega que o "republicanismo seja uma forma específica de comunitarismo" (HONOHAN, 2002, p. 8). Pinzani (2005) defende uma definição do republicanismo sustentada em virtude cívica, governo das leis e concepção de liberdade. 
a ocorrência de falta de liberdade da imposição de interferência” (SKINNER, 1998, p. 89). Essa definição, caminhando no sentido contrário àquela de Pettit, embora concordando com o conteúdo, é na verdade o resultado de uma argumentação eminentemente histórica, mas que, aqui, implica afirmar a possibilidade de uma condição necessária, ainda que relacionada a outras, como o autogoverno e a participação instrumental. A síntese proposta nesse artigo tem, em parte, inspiração, não no conteúdo completamente, mas na maneira de observar a relação entre as reconstituiçôes históricas criticamente através de conceitos.

\section{Conclusão}

Existe um motivo para essa variedade de abordagens. O percurso dos movimentos e pensamentos republicanos na modernidade ocorreu de modo relativamente descontínuo, temporal e espacialmente, o que justifica as opçóes pelas reconstruçóes históricas salteadas de contexto em contexto. Geralmente, reconhece-se que o republicanismo teve início nas cidades do renascimento italiano, passou para as guerras civis inglesas e, de lá, para a revolução americana. Há casos em que o iluminismo francês e/ ou escocês é identificado como um passo importante, bem como o século XIX na Europa continental; outros alocam esses contextos fora da tradiçáo ítalo-atlântica, mas são considerados igualmente republicanos. Não obstante as particularidades teóricas de cada contexto, o esforço reconstrutivo em geral visa a tornar explícitas as continuidades, ainda que com destaques às nuanças particulares.

Há, porém, um enorme conjunto de situações nacionais e regionais em diversos períodos que quase sempre é negligenciado, salvo estudos de casos específicos e muito menos conhecidos. As revoltas holandesas do século XVI e XVII contra o domínio espanhol, os cantôes suíços e germânicos em diversos momentos da modernidade, a Polônia dos séculos XVII e XVIII, a América Latina durante os processos de independência, a Alemanha ao longo da unificação, a Espanha de fins do século XIX, Portugal de inícios do XX, Irlanda, ao longo do XX são apenas alguns exemplos.

A marca dessas manifestaçóes reside na irredutível defesa do autogoverno em franca oposição ao autoritarismo interno ou ao domínio externo, 
sob o signo da liberdade, da cidadania e participação, do império da lei e do controle dos poderes; logo, não surpreende que a produção intelectual dessas regióes seja igualmente pujante se contrastada com os países mais estudados. Na verdade, parece ser justamente o fato de o republicanismo, como doutrina estabelecida na história do pensamento político como uma alternativa de ação e de programa, ser embasado nas manifestações dos países centrais do mundo, pelo menos desde o renascimento, que moldou o próprio entendimento do que seja o republicanismo. Em outros termos, o acúmulo de pesquisa e divulgação sobre o renascimento italiano, as guerras civis inglesas, a revolução americana e o iluminismo parece ter sido a causa - e não a consequência - principal para que se identifique o republicanismo com essas manifestaçóes. De fato, esforços no sentido oposto têm sido feitos em anos recentes, ou seja, o de investigar as particularidades e contribuiçóes dos republicanismos em regiôes periféricas, não apenas na Europa, mas em várias partes do globo ${ }^{16}$.

Seja como for, há algo bem interessante na diversidade de trajetórias. Existe um determinado acúmulo nas mobilizações teóricas de tal maneira que é possível identificar a presença de autores em proposiçóes republicanas posteriores. $\mathrm{O}$ uso de Maquiavel na Inglaterra é um dos exemplos mais característicos e estudados. Marchamont Nedham, James Harrington, Algernon Sidney, Henry Neville, principais expoentes do republicanismo inglês, mobilizam o secretário de Florença em franca relação com seus programas e teorias republicanas. $\mathrm{O}$ mesmo ocorre com a revoluçáo americana, que ainda acumula o emprego dos personagens ingleses. Aliás, o Seiscentos inglês é importantíssimo ainda hoje, por exemplo, para a concepção de liberdade do republicanismo neorromano. Rousseau, Mably, Condorcet e Sieyès são constantemente relembrados durante o século XIX francês e continental como um todo, além dos movimentos de independência latino-americanos. Ainda que não francamente um republicano, as análises de Montesquieu sobre esse regime foram decisivas na fundação dos Estados

16 Os dois volumes organizados por Skinner e Gelderen (2002) buscam apresentar algumas dessas considerações de fora do eixo central europeu, embora todos os casos analisados, por diversos pesquisadores de diversos países, tenham esse continente como referência. Para citar apenas parte da bibliografia mais recente sobre o Brasil, de caráter eminentemente histórico, conforme: Alonso, 2002; Bignotto, 2020; Carvalho, 2018; Fonseca, 2016; Lemos, 2000; Mello, 2007; Starling, 2018. 
Unidos, bem como a ilustração escocesa. Aliás, ambos os movimentos revolucionários, americano e francês, dialogavam quase que simultaneamente aos acontecimentos de fins do século.

Esse conjunto de exemplos, que poderia ser multiplicado muitas vezes com bibliografias cada vez mais especializadas, corrobora com a hipótese de que o republicanismo pode e deve ser entendido como uma tradição em seu sentido mais próprio do termo, de tal modo que as linhas de continuidade possam ser lidas, estudadas e sustentadas. Mas é justamente pelo fato de que há uma tradição republicana ocidental que se deve ter muita cautela no momento de sua definição mais singela. É preciso ter claro, entretanto, que nem todas as recepçôes são positivas. Muitas delas negam as versóes republicanas anteriores, mas isso, ao invés de depor contra a existência de uma tradição, apenas corrobora com ela. Assim, trata-se de uma verdadeira sobreposição de camadas históricas cujos conceitos centrais se fixam, se aprofundam ou se modificam, ou, ainda, são rejeitados a cada inovação. Mas o que faz do republicanismo uma tradição teórica é exatamente o fato de que há conceitos que, de algum modo, se mantêm no tempo e se espraiam pelos lugares. E, por isso, a síntese republicana oferece uma chave de saída para os problemas de definição. Em suma, esses conceitos centrais aqui repetidos muitas vezes são expressos de maneiras e com importâncias diferentes em contextos diferentes, mas não deixam de ser aludidos. É no acúmulo das experiências históricas que a síntese teórica do republicanismo se apresenta.

Iniciamos esse artigo com a argumentação que a excepcionalidade francesa pode e tem sido questionada nos últimos anos; ainda assim, essa versão é reconhecida e respeitada como um lugar-comum do republicanismo. Em si mesma, a tese da excepcionalidade francesa deve ser questionada pelo seu exclusivismo, o que quer dizer que, nas versóes mais radicais, é republicanismo aquilo que é excepcionalidade francesa. Esse ponto é importante para marcar náo apenas a dificuldade do debate atual em reconhecer linhas de continuidade teórica entre o universo ítalo-atlântico e o pós-revolução francesa, mas, sobretudo, que seu expediente fundamental, via de regra, não é exatamente distinto daquele empregado pelas teorias mais normativas da atualidade em modos muito similares a uma tautologia. 
Para fugir de uma definição no mais das vezes tautológica de republicanismo, há muito bem-sucedidos casos nos quais a reconstrução histórica se sobrepóe àquela conceitual, o que náo significa afirmar a superioridade desta sobre aquela. Pelo contrário, argumentamos que os limites de uma abordagem histórica ou histórica com tipificaçóes conceituais, acabam por negligenciar os diferenciais teóricos do republicanismo em relação a outras tradiçóes de pensamento político moderno. Por um lado, se uma abordagem estritamente tautológica se torna eminentemente útil por uma definiçãao precisa e rigorosa, por outro, ela cai em paroxismos de se verem forçadas a reconhecer republicanismos onde a estrutura mais básica dessa linguagem estava ausente. A abordagem histórica, pelo contrário, foge de tautologias e paroxismos, mas perde em clareza e utilidade.

O caminho do meio parece ser algo tentador e vamos concluir defendendo-o. A melhor forma de encontrar uma definição de republicanismo simultaneamente útil e rigorosa é unir conceito e contexto. E aqui não há nenhuma novidade, pois o percurso republicano é repleto de exemplos assim. A análise das condiçóes necessárias pode ser empregada em contextos diferentes atribuindo importâncias diferentes a cada conceito.

No renascimento italiano, os temas da virtude e do governo misto se sobrepunham aos do império da lei e da igualdade perante as leis. Porém, já nas guerras civis inglesas, o império da lei torna-se peça fundamental, a igualdade é um requisito e a virtude começa a abrir espaço para o interesse. Muitos observam no século XVIII a mais importante inflexão do republicanismo moderno, porque absorveu o federalismo, a ideia de nação, o sufrágio, a representação em certa oposição aos termos pensados a partir da Antiguidade. Aprofundar-se-iam esses pontos ao longo do século XIX, particularmente continental. Todavia, e talvez esse seja um ponto que muitos se negam a reconhecer, os termos conceituais mestres da tradição republicana permanecem presentes em quase todas as experiências, salvo, claro, exceções de autores e especificidades contextuais limítrofes. Por isso, o ponto mais frutífero parece ser identificar, do ponto de vista de uma explicação útil e rigorosa sobre o que seja o republicanismo, e buscar unir cada um desses conceitos à luz das condiçóes históricas e, com elas, compreender o modo pelo qual um se sobrepóe, corrobora ou nega outros. 
É na articulação teórica dos conceitos centrais, dado o contexto, que o republicanismo mostra sua potência.

Para concluir, o ponto central náo é identificar o republicanismo de modo taxativo e perene, mas partir do reconhecimento de que ele é dinâmico. Seus denominadores comuns - a liberdade relacionada à igualdade, o governo misto, o império das leis, o antiautoritaríssimo, a cidadania e a virtude - encontram-se em quase todas as suas experiências, embora com importâncias relativas diferentes, inclusive, a depender do autor. Responder à pergunta "o que é o republicanismo?" por um conjunto de condicionantes que o caracterizam pode ser uma tarefa frutífera se isso for feito mediante os contextos e, assim, torná-lo visível ao observador minimamente atento.

\section{Referências}

ALONSO, Â. Ideais em movimento: a geração de 1870 na crise do Brasil-Império. Rio de Janeiro: Paz e Terra, 2002.

AUDIER, S. Les théories de la république. Paris: La Decouverte, 2004.

ARAÚJO, C. A forma da república: da constituiçâo mista ao Estado. São Paulo: Martins Fontes, 2014 .

BALESTRIERI, G. Machiavelli e la doppia fondazione della dottrina dei conflitti sociali. La cultura, anno XLVIII, n. 3, p. 459-499, 2010.

BACCELLI, L. Critica del repubblicanesimo. Bari: Laterza, 2003.

BERLIN, I. [1958]. Two concepts of liberty. In: HARDY, H.; HAUSHEER, R. (ed.). The proper study of mankind: an anthology of essays. London: Chatto \& Windus, 1997.

BELLAMY, R. Republicanism, democracy, and constitutionalism. In: LABORDE, C.; MAYNOR, J. (ed.). Republicanism and political theory. Oxford: Blackwell Publishing, 2008. p. 159-189.

BIGNOTTO, N. (org.). Matrizes do republicanismo. Belo Horizonte: UFMG, 2013.

BIGNOTTO, N. O Brasil à procura da democracia: da proclamação da república ao século XXI (1889-2018). Rio de Janeiro: Bazar do Tempo, 2020.

BRUGGER, B. Republican theory in political thought: Virtuous or virtual? London: Macmillan Press, 1999.

CARVALHO, J. M. de. “Clamar e agitar sempre” - os radicais da década de 1860. Rio de Janeiro: Topbooks, 2018. 
DAGGER, R. Civic virtue: rights, citizenship, and republican liberalism. Oxford: Oxford University Press, 1997.

DAVIS, J. C. The romance of 1650s as a context for Oceana. In: WIEMANN, D.; MAHLBERG, G. (ed.). Perspectives on English revolutionary theory. Burlington: Ashgate, 2013. p. 65-84.

DOMÈNECH, A. Droit, Droit Naturel et tradition républicaine moderne. In: Républicanismes et Droit Naturel: des humanistes aux révolutions des droits de l'homme et du citoyen. Paris: Éditions Kimé, 2009. p. 17-30.

DZELZAINIS, M. Anti-monarchism in English Republicanism. In: SKINNER, Quentin; GELDEREN, M. van (ed.). Republicanism: a shared European heritage. Cambridge: Cambridge University Press, 2002. v. 1. p. 27-42.

FALCÁO, L. Maquiavel, Montesquieu e Madison: uma tradição republicana em duas perspectivas. Rio de Janeiro: Azougue, 2013.

FALCÁO, L. Republicanismo neorromano e liberalismo: para além das proximidades declaradas. Revista Brasileira de Ciência Política, Brasília, n. 24, p. 115-158 set./dez. 2017.

FALCÃO, L. Algernon Sidney: um pensador republicano do século XVII. Niterói: EdUFF, 2019.

FONSECA, S. C. P. de B. A ideia de República no Império do Brasil. Jundiaí: Paco Editorial, 2016.

GEUNA, M. La tradizione repubblicana e suoi interpreti: famiglie teoriche e discontinuità concettuali. Filosofia Politica, n. 12, v. 1, p. 101-132, 1998.

GRANGE, J. L’idée de République. Paris: Pocket, 2008.

HAMEL, C. Prendre la vertu et le droit sérieux: l'hypothèse d'un républicanisme des droits. Les Études Philosophiques, Paris, v. 4, n. 83, p. 499-517, 2007.

HAMEL, C. Le républicanisme des droits. Enjeux conceptuels d'un passé utile. In: Républiques et républicanismes - les cheminements de la liberté. Sous la direction de Olivier Christin. Lormont: Le Bord de L'eau, 2019. p. 79-98.

HAMMERSLEY, R. Republicanism: an introduction. Cambridge: Polity, 2020.

HANKINS, J. Exclusivist republicanism and the non-monarchical republic. Political Theory, v. 38, n. 4, p. 54-70, 2010.

HONOHAN, I. Civic republicanism. London: Routledge, 2002.

KALYVAS, A.; KATZNELSON, I Liberal beginnings: making a Republic for the Moderns. Cambridge: Cambridge University Press, 2018.

KRIEGEL, B. Philosophie de la république. Paris: Plon, 1998.

LEMOS, R. Republicanos e libertários: pensadores radicais no Rio de Janeiro (1822). Rio de Janeiro: Civilização Brasileira, 2000. 
MAIHOFER, W. The ethos of the republic and the reality of politics. In: BOCK, G.; SKINNER, Q.; VIROLI, M. (org.). Machiavelli and republicanism. Cambridge: Cambridge University Press, 2002. p. 283-292.

MAISSEN, T. Républiques et républicanisme en époque moderne : théories et pratiques dans une perspective occidentale. In: CHRISTIN, O. (dir.). Républiques et républicanismes - les cheminements de la liberté. Lormont: Le Bord de L'eau, 2019. p. 27-46.

MARKELL, P. The insufficiency of non-domination. Political Theory, v. 36, n. 1, p. 9-36, 2008.

MAYNOR, J. Republicanism in the modern world. Cambridge: Blackwell Publishing Ltd, 2003.

MELLO, M. T. C. de. A república consentida. Rio de Janeiro: FGV, 2007.

PETTIT, P. Republicanism: a theory of freedom and government. Oxford: Oxford University Press, 1997.

PETTIT, P. On the people's terms: a republican theory and model of democracy. Cambridge: Cambridge University Press, 2012.

PETTIT, P. Two republican traditions. In: NIEDERBERGER, A.; SCHINK, P. (org.). Republican democracy: liberty, law and politics. Edinburgh: Edinburgh University Press, 2013.

PETTIT, P. Just freedom: a moral compass for a complex world. New York: W. W. Norton \& Company, 2014.

POCOCK, J. G. A. The ancient constitution and the feudal law. Cambridge: Cambridge University Press, 1987.

POCOCK, J. G. A. The machiavellian moment: Florentine political thought and the Atlantic republican tradition. 2. ed. Princeton: Princeton University Press, 2003.

SAINT VICTOR, J.; BRANTHÔME, T. Histoire de la république en France. Paris: Economica, 2018.

SCHWARCZ, L.; STARLING, H. (org.). Dicionário da república: 51 textos críticos. São Paulo: Companhia das Letras, 2019.

SILVA, R. Visões da liberdade: republicanismo e liberalismo no debate teórico contemporâneo. Lua Nova, v. 94, p. 181-215, 2015.

SILVESTRINI, G. Fra repubblicanesimo e giusnaturalismo: itinerari nella storia del pensiero politico moderno. Torino: Cortina, 2008.

SKINNER, Q. The paradoxes of political liberty. The tanner lectures on human values, v. 25, p. 226-250, 1984.

SKINNER, Q. Liberty before liberalism. Cambridge: Cambridge University Press, 1998.

SKINNER, Q. A third concept of liberty. Proceedings of the British Academy, v. 117, p. 237268, 2002a. 
SKINNER, Q. Visions of politics II: renaissance virtues. Cambridge: Cambridge University Press, 2002b.

SKINNER, Q.; GELDEREN, M. van (ed.). Republicanism: a shared European heritage. 2 vol. Cambridge: Cambridge University Press, 2002.

SPITZ, J.-F. La liberté politique. Paris: PUF, 1995.

SPITZ, J.-F. Le moment républicain en France. Paris: Gallimard, 2005.

STARLING, H. Ser republicano no Brasil colônia: a história de uma tradição esquecida. São Paulo: Companhia da Letras, 2018.

TENZER, N. La république. Paris: PUF, 1993.

VIROLI, M. Republicanism. New York: Library of the Congress, 2002.

WOOTTON, D. Republicanism and restoration: 1660-1683. In: WOOTTON, D. (ed.). Republicanism, liberty, and commercial society - 1649-1776. Stanford: Stanford University Press, 1994. p. 139-193.

ZUCKERT, M. Natural rights and the new republicanism. Princeton: Princeton University Press, 1994.

Recebido em 21/01/2021

Aprovado em 07/04/2021 


\section{Defining Republicanism: approaches, difficulties, and synthesis}

\section{Abstract}

The paper presents a synthesis of the different and recently definitions of the republicanism. First, there is a critical analysis of the different approaches that aim the definition in the way of the opposite traditions, the problem of the tautology of the definition, and the exaggerated extrapolations. In the second moment, the paper argues that the supposed exception of the French republicanism is, by the way, more like the Anglo-Saxon tradition than is commonly accepted. So, the strategy of the historical definition turns more difficulty to the conceptual approaches. And then, the paper argues that the normative definitions explicitly dialogue with the contemporary political theories. In the end, the paper argues that is possible to elaborate a definition by a synthesis of these approaches, concepts, and contexts.

Keywords: Republicanism. French exception. Historical approaches. Normative Definition. 